\title{
Eltérő felsőfokú végzettségek és szakképzettségek hatásának vizsgálata a munkavállalók digitális kompetencia állapotára
}

\section{Bevezető gondolatok}

Ma már vitathatatlan, hogy a 21. század munkavállalóinak a munka világában elfoglalt helyüktől és szerepüktől függetlenül használható digitális kompetenciával kell rendelkezniük. Különösen igaz ez az állítás a könyvtári szakemberekre, akik esetében az információs mủveltség, a digitális készségek magas szintủ birtoklása alapvető elvárásként fogalmazódik meg. Jelen tanulmány az Európai Bizottság kezdeményezésére 2013-ban megjelent DigComp keretrendszerben megtestesült digitáliskompetencia-értelmezést tekinti mérvadónak. ${ }^{1}$ Eszerint a digitális kompetencia magába foglalja a digitális környezetben történő információkezelést, kommunikációt, tartalomelóállítást, biztonsági kérdéseket és a problémamegoldást. Ezek a kompetenciaterületek számos kompetenciát tartalmaznak, amelyek többsége csak tanulás és gyakorlás útján sajátítható és mélyíthető el. A digitális kompetencia fejlesztésében a közoktatás rendszere mellett kiemelkedően nagy szerepe van a felsőoktatásnak is. A felsőfokú könyvtárosképzést folytató képzőhelyek a vonatkozó szakok képzési és kimeneti követelményeit folyamatosan korszerüsítve igyekeznek megfelelni a kor kihívásainak. A felsőoktatási intézmények törekvése ellenére azonban a könyvtáros szakma részéröl az utóbbi időben kritikus észrevételek fogalmazódtak meg a felsőfokú könyvtárosképzéssel kapcsolatban. A szakkönyvtárak fejlesztési irányait taglaló írásukban a szerzők egyenesen úgy fogalmaztak, hogy nincs megfelelöen szakképzett utánpótlás. ${ }^{2}$ Lévén szó szakkönyvtári stratégiáról, joggal feltételezhető, hogy a szerzők által hiányolt kompetenciák jelentős része a digitális jártasság körébe sorolandó, bár a hivatkozott dokumentumból nem derül ki egyértelmüen, hogy mit is hiányolnak valójában a szakkönyvtárak.

Ma a könyvtárakban könyvtári szakemberként a „kulturális törvény”3 megfogalmazása szerint könyvtárosok, könyvtári informatikusok, könyvtári asszisztensek, segédkönyvtárosok, továbbá a könyvtári feladatok ellátásához szükséges

${ }^{1}$ Ferrari, Anusca: DIGCOMP: A Framework for Developing and Understanding Digital Competence in Europe. Luxemburg, Publications Office of the European Union. 2013. http://ftp. jrc.es/EURdoc/JRC83167.pdf (2019. május 21.) DOI:10.2788/52966

${ }^{2}$ Gaálné Kalydy Dóra - Monok István - Rózsa Dávid: A szakkönyvtárak stratégiai fejlesztési irányai 2019-2024. https://konyvtar.mta.hu/download/dokumentumok/strategia2019_v2.pdf. (2019. október 2.)

${ }^{3}$ 1997. évi CXL. törvény a muzeális intézményekröl, a nyilvános könyvtári ellátásról és a közmüvelödésről. https://net.jogtar.hu/jogszabaly?docid=99700140.TV. (2019. október 2.) 
más felső- vagy középfokú végzettséggel rendelkező személyek dolgozhatnak. Könyvtárosnak kizárólagosan a könyvtáros felsőfokú szakirányú végzettséggel rendelkező szakember tekinthető.

Joggal merül fel a kérdés, hogy vajon a könyvtáros diplomával rendelkező szakemberek és az egyéb diplomás könyvtári szakemberek digitáliskompetencia-állapota között van-e érzékelhető különbség. Továbbá figyelmet érdemel annak a kérdésnek a tanulmányozása is, hogy a könyvtárosképzés mennyire képes lépést tartani a digitális kompetencia fejlesztése területén meglévő kihívásokkal. Ez a kérdés leginkább a jelenlegi és a végzett hallgatók időnkénti vizsgálatával válaszolható meg. Tágabb kontextusban is érdemes lehet felmérni az eltérő végzettségek digitális kompetenciára gyakorolt hatását, és ezeket az eredményeket összevetni a felsőfokú könyvtáros végzettséggel rendelkezők körében tapasztaltakkal. Természetes viszonyítási csoport lehet a pedagógusoké, hiszen a könyvtári terület számos ponton kapcsolódik az oktatáshoz.

Jelen tanulmány elsősorban az előbbiekben feltett kérdésekre, felvetésekre igyekszik hiteles választ adni a közelmúltban lezajlott kutatások eredményei alapján.

\section{Vizsgálatok a digitális kompetencia területén}

A Múzeumi és könyvtári fejlesztések mindenkinek EFOP-3.3.3-VEKOP/162016-00001 projekt keretében, Az én könyvtáram programban 2017-ben két országos reprezentatív digitáliskompetencia-felmérést sikerült lebonyolítani. 1785 fö közkönyvtárakban dolgozó könyvtáros és 822 fö pedagógus, köztük 116 informatikatanár vett részt a vizsgálatokban.

2019-ben az Integrált kutatói utánpótlás-képzési program az informatika és számitástudomány diszciplináris területein (EFOP-3.6.3-VEKOP-16-201700002) adott lehetőséget 200 fó gazdaságinformatikus egyetemi hallgató és 27 fó informatikus könyvtáros hallgató digitális jártasságának felmérésére. A könyvtáros hallgatók esetében ez az alacsony létszám sajnos a reprezentatív mintáját jelenti a végzés előtt álló hallgatóknak.

Valamennyi vizsgálat kérdőíves önbevallás formájában történt, és a kérdések a DigComp keretrendszer legelső, 2013-as verziójára épültek. ${ }^{4}$ Öt kompetenciaterületen huszonegy kompetencia szintjének felmérése valósult meg. Ezek a következők voltak:

- információ: keresés, értékelés, tárolás és visszakeresés;

- kommunikáció: technológia használata, tartalommegosztás, online polgár, együttmüködés, etikett, digitális identitás;

${ }^{4}$ Ferrari, Anusca: DIGCOMP: A Framework for Developing and Understanding Digital Competence in Europe. Luxemburg, Publications Office of the European Union. 2013. http://ftp. jrc.es/EURdoc/JRC83167.pdf (2019. május 21.) https://doi.org/10.2788/52966. 
- tartalom-előállítás: fejlesztés, újraformálás, szerzői jog, programozás;

- biztonság: eszközvédelem, adatvédelem, egészségvédelem, környezetvédelem;

- problémamegoldás: technikai problémák megoldása, technológiaválasztás, kreatív felhasználás, kompetenciahiány azonosítása.

A felsorolásból egyértelmủen kitünik, hogy a DigComp nagyon komplex és korszerủ megközelítést nyújt a digitális kompetencia tanulmányozásához. Minden egyes kompetencia esetében három jártassági szintet határoz meg a keretrendszer: alap, közepes és haladó szinteket.

$\mathrm{Az}$ 1. ábrán a négy vizsgált csoport digitáliskompetencia-szintek szerinti rétegződését láthatjuk. Messzemenő következtetések levonására ez az összegző ábra természetesen önmagában nem alkalmas, de arra igen, hogy jelezze a csoportok közötti hasonlóságokat és eltéréseket. A leginkább kompetenseknek egyértelmủen a jelenleg egyetemi éveikben járó hallgatók bizonyultak. Az informatikus könyvtáros hallgatók 56 százaléka, a gazdaságinformatikus hallgatók 42 százaléka rendelkezik haladó digitális jártassággal. Ezekkel az értékekkel jelentősen megelőzik mind az aktív könyvtárosokat, mind pedig az aktív pedagógusokat. Az alapszinten álló egyetemisták aránya 12-15 százaléknyi, míg az aktív könyvtárosok körében 31, a pedagógusok körében pedig 33 százalék az alapszint aránya. Ugyanakkor meg kell jegyezni, hogy az egyetemisták kompetenciaelőnye elsősorban a szakjaik jellegéből, nem pedig az életkorukból adódik. Természetesen van néhány, kifejezetten életkorfüggő digitális kompetencia, de ezek száma nem jelentős.

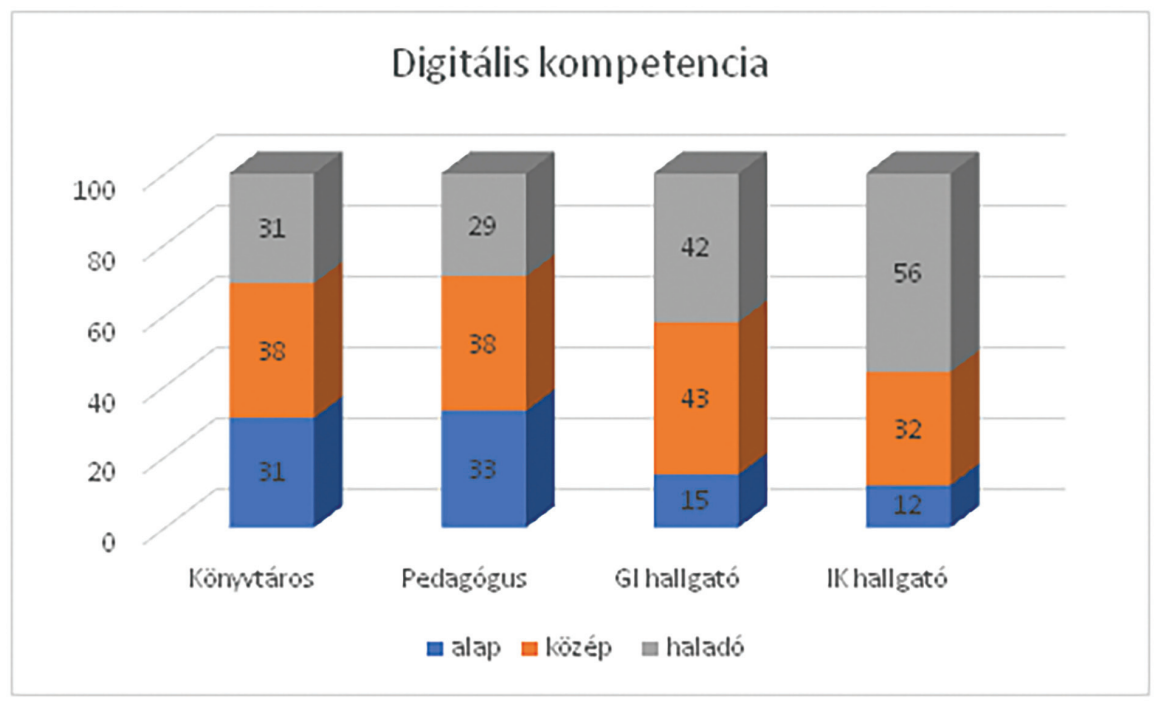

1. ábra. A négy vizsgált csoport digitális kompetencia állapota 
A már dolgozó könyvtárosok és pedagógusok digitáliskompetencia-mutatói nagyon hasonlóak, a könyvtárosoké valamivel jobbak. Az utóbbi eredménynek azért is van különösen nagy jelentösége, mert a pedagógusok közül nagyon sok informatikatanár vett részt a felmérésben.

\section{A digitálisan kompetens könyvtári szakemberek}

A közel 1800 fő közkönyvtárakban dolgozó, a korábbiakban említett vegyes végzettséggel és szakképzettséggel rendelkező könyvtári szakember kompetencia felmérése a 2. ábrán látható eredménnyel zárult. A kompetenciaterületek közül az információ kezelésében állnak a legtöbben haladó szinten és a legkevesebben alapszinten. A digitális környezetben történő kommunikáció is viszonylag erős területe a könyvtárosoknak, a haladó jártassággal rendelkezők aránya 36 százalék, és lényegesen meghaladja a csak alapjártassággal rendelkezők arányát. A további három kompetenciaterületen már komoly hiányosságokat tárt fel a vizsgálat. A biztonság, a tartalom-előállítás és a problémamegoldás területén arányaiban a haladó szinten lévők vannak a legkevesebben. A 2017-es könyvtáros kompetenciavizsgálat részletes ismertetését a szerző egyik korábbi tanulmánya tartalmazza. ${ }^{5}$

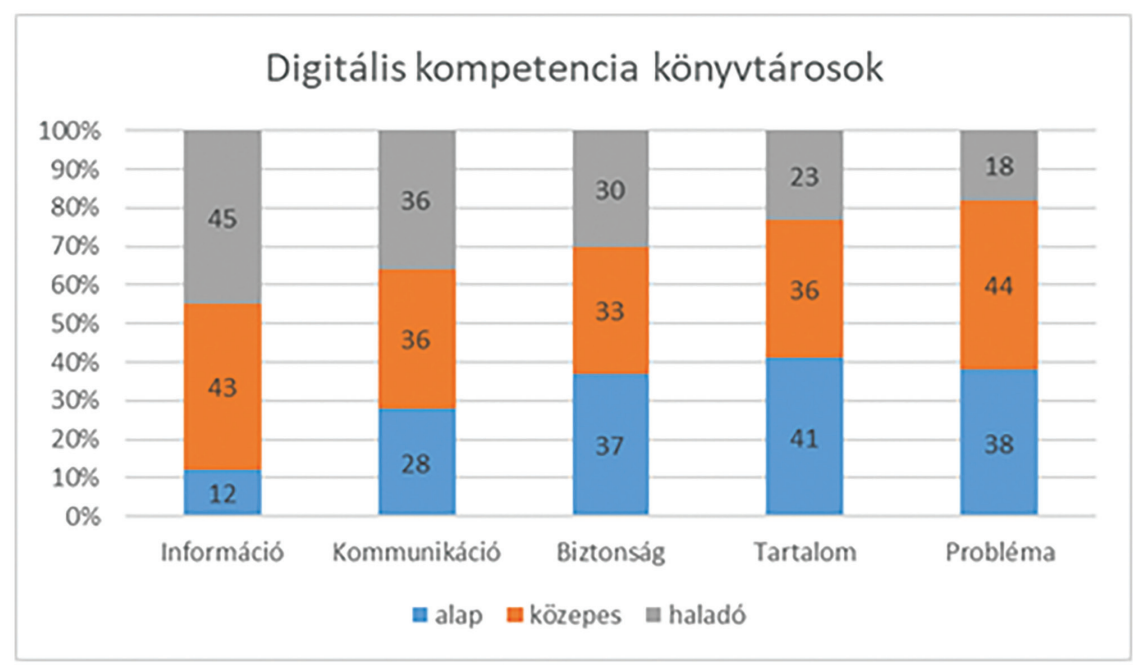

2. ábra. Könyvtárosok digitális kompetencia állapota

A könyvtári szakemberek digitális jártassága azonban sokkal árnyaltabb képet mutat, ha részletesen elemezzük a különböző végzettséggel és szakképzettséggel rendelkezők eredményeit. A DigComp-ot létrehozók szándéka szerint a ke-

${ }^{5}$ Eszenyiné Borbély Mária: A magyar települési könyvtárakban dolgozó könyvtárosok digitális kompetenciájának állapota: egy országos reprezentatív vizsgálat eredményei. = Információs Társadalom: Társadalomtudományi Folyóirat, 18. évf. 2018. 3-4. sz. 46-81. p. https://doi.org/ 10.22503/inftars.XVIII.2018.3-4.3 
retrendszer az átlag állampolgár digitális készségeit hivatott felmérni. Így talán nem túlzás a könyvtárosokkal mint információs szakemberekkel szemben azt az igényt megfogalmazni, hogy lehetöség szerint a kompetenciák minél nagyobb körében haladó jártassággal rendelkezzenek. A különböző végzettséggel rendelkező könyvtári szakemberek haladó szintü jártasságát az egyes kompetenciák szerint részletezve a 3. ábra tartalmazza. A könyvtáros diplomával rendelkezö könyvtári szakemberek a vizsgált 21 digitális kompetenciából 20 esetében nagyobb arányban állnak haladó jártassági szinten, mint az egyéb diplomával vagy érettségivel rendelkező szakemberek, akik alapvégzettségüket jellemzően kiegészítették könyvtáros asszisztensi vagy segédkönyvtárosi képesítéssel. Az egyetlen kompetencia, amelyet az egyéb diplomával rendelkezők birtokolnak a könyvtáros diplomásoknál nagyobb arányban haladó szinten, a digitális személyazonosság menedzselése. Ugyanakkor 10 százaléknyi vagy azt meghaladó arányfölénnyel állnak haladó szinten a könyvtáros felsőfokú végzettséggel rendelkezők olyan fontos kompetenciák esetében, mint az online aktivitás, az adott feladathoz leginkább illeszkedő eszközzel, alkalmazással történő problémamegoldás, az információkeresés, a megtalált információ és forrás értékelése, tárolása, visszahívása, új digitális tartalom létrehozása, vagy már meglévő módosítása, a tartalommegosztás, az egészségvédelem és a környezetvédelem. Az előbbiektől alig marad el a könyvtáros diplomával rendelkezők előnye a digitális technológia kreatív használata, az adatvédelem, az eszközvédelem és a kollaboráció területén. Tehát tényként állapítható meg, hogy a felsőfokú könyvtárosképzés kifejezetten erőteljesen hat a digitális készségekre.

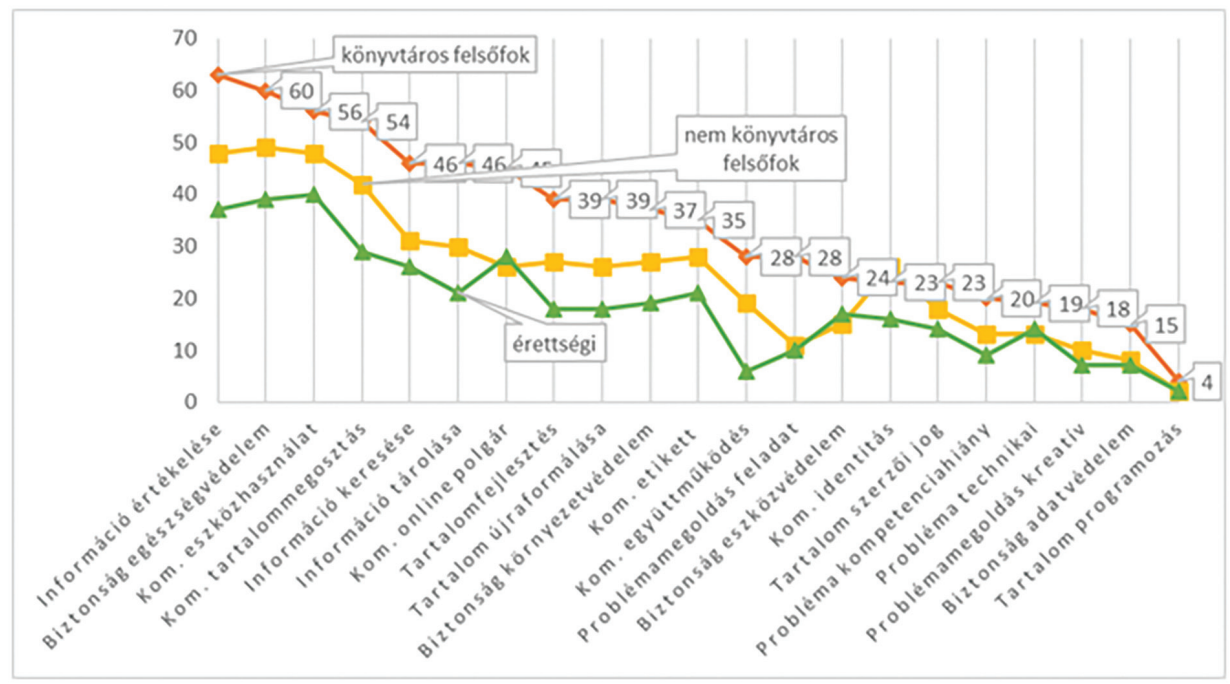

3. ábra. Eltérő végzettségü könyvtári szakemberek haladó jártassági szintjei 
Amennyiben a könyvtári munkáltatói elvárásokban digitálisan kompetens munkavállalók iránti igény fogalmazódik meg, akkor a vizsgálat tanúsága szerint a legjobb döntés a felsőfokú könyvtáros végzettséggel rendelkező dolgozók alkalmazása.

\section{A digitálisan kompetens pedagógusok}

A pedagógusok digitális kompetencia állapota - a könyvtárosokhoz hasonlítva az öt kompetenciaterületen elért eredményeiket - csak kismértékben tünik gyengébbnek. A könyvtárosok egyértelműen erősebbek az információ kezelése területén, de ez nem lehet meglepő, hiszen ez a szakmájuk egyik lényegi eleme. Egy érdekes adalék a pedagógus eredményekhez, hogy ha az informatikatanárok nélkül számítjuk ki a különbözö jártassági szinteken lévők arányát, azt láthatjuk, hogy az információ menedzselésén kívül nem változik lényegesen a helyzet. Ugyanakkor az információkezelés már lényegesen gyengébb képet mutat az informatikatanárok nélkül. A pedagógusok körében lecsökken a haladó jártassággal rendelkezők aránya 39 százalékra, és megnő az alapszinten állók tábora 18 százalékra. A többi kompetenciaterületet vizsgálva is az látszik, hogy a könyvtárosok közül a pedagógusokhoz mérten jellemzően nagyobb arányban állnak haladó, és kevesebben alapszinten.

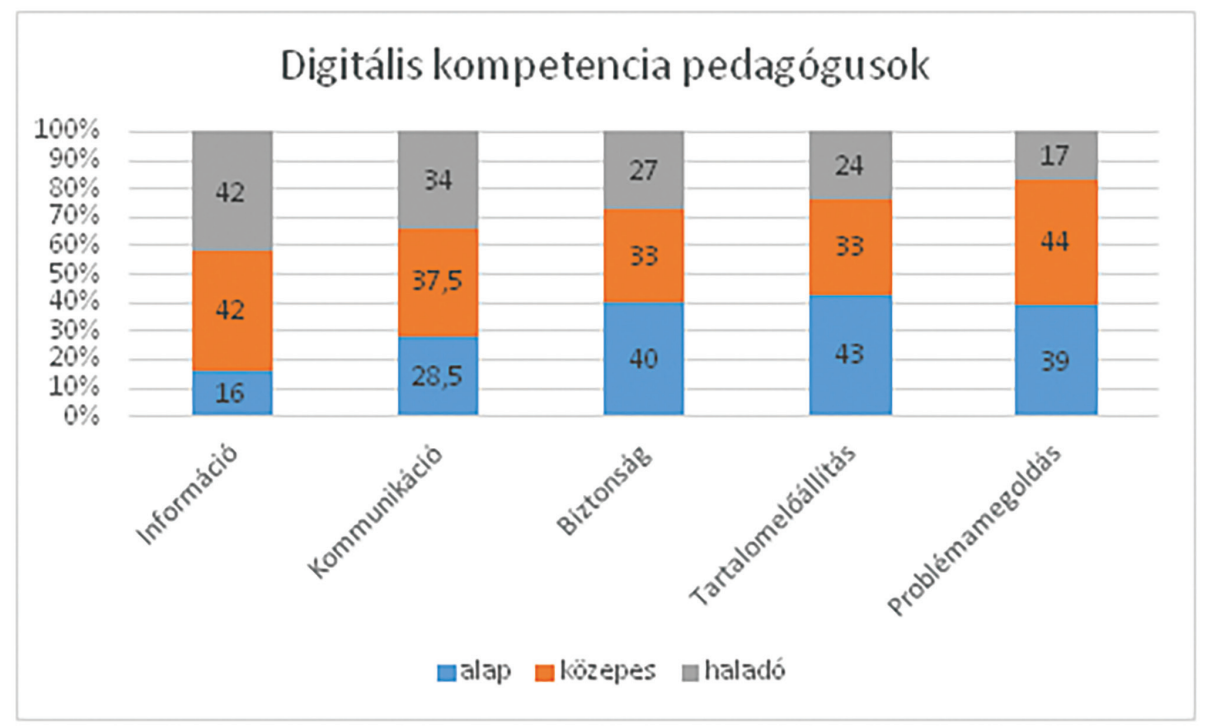

4. ábra. Pedagógusok digitális kompetencia állapota

Azokat az esetleges illúziókat is fel kell számolni, hogy bizonyos szakos, bizonyos műveltségterületen dolgozó pedagógusok (kivéve természetesen az informatikatanárokat) digitálisan felkészültebbek a többieknél. Az 5. ábrán látható, hogy a kü- 
lönböző müveltségi területeken tanító pedagógusok jártassági szintjei között csak minimális eltérések vannak az információ kompetenciaterületen, és ehhez hasonló a jártassági szintek megoszlása a további kompetenciaterületeken is. ${ }^{6}$

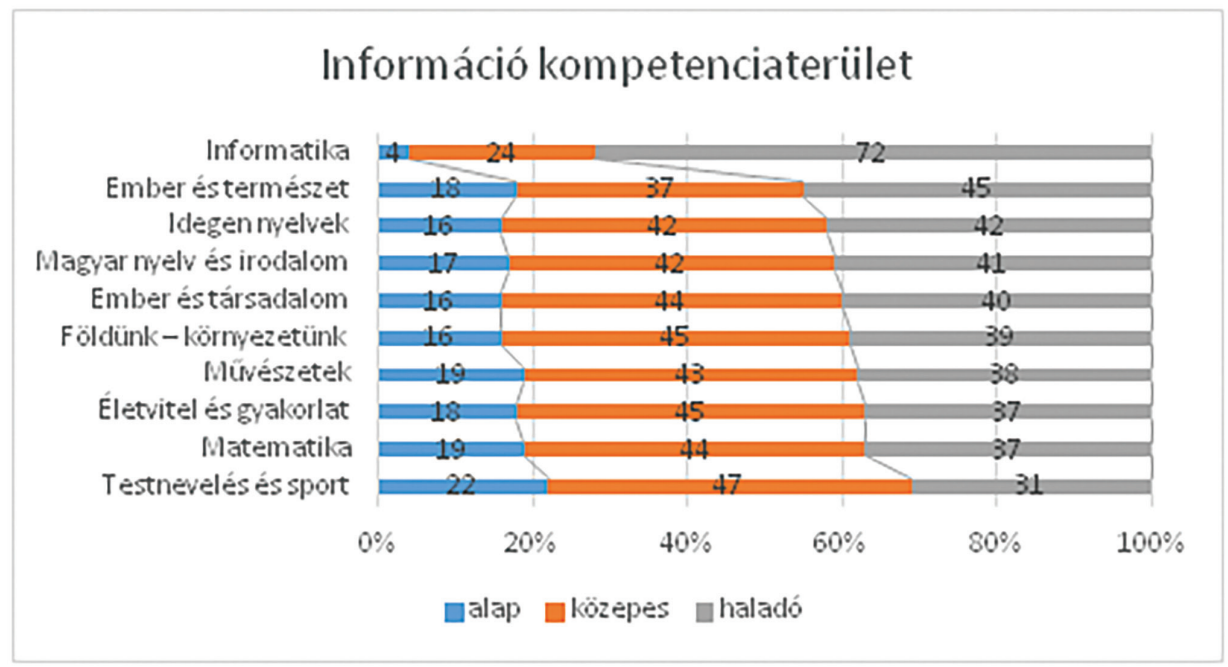

5. ábra. Információ kompetenciaterület pedagógusok

\section{A felsőfokú könyvtáros végzettséggel rendelkező könyvtárosok és a pedagó- gusok digitális kompetencia állapota}

Az eddigi pedagógus-könyvtáros összehasonlításban a könyvtári szakemberek egészére vonatkozó adatsorok szerepeltek, tekintet nélkül a könyvtárosok végzettségére. A következőkben a könyvtári szakemberek közül a felsőfokú szakirányú végzettséggel, tehát a könyvtáros diplomával rendelkezö könyvtárosok és a pedagógusok digitális kompetenciáinak összehasonlító elemzésére kerül sor. Az adatok értelmezését a 6 . ábra is segíti.

A könyvtárosok körében a DigComp 21 kompetenciája közül 17 esetében nagyobb arányban fordulnak elő haladó szintü jártassággal rendelkezők, mint a pedagógusok között. Három kompetenciát a könyvtárosok és a pedagógusok azonos arányban birtokolnak haladó szinten, ezek a digitáliskompetencia-hiány érzékelése, az online etikett és a digitális tartalom létrehozása. Egyetlenegy kompetenciában bizonyultak a pedagógusok jobbnak, a programozásban. Ebben 6 százalékuk rendelkezik haladó jártassággal, míg a könyvtárosoknak csak 4 százaléka. A pedagógusok szerény fölényének magyarázata valószínűleg az lehet, hogy az informatikatanárok számaránya viszonylag magas volt a vizsgálatban.

${ }^{6}$ Eszenyiné Borbély Mária: Pedagógus digitális kompetencia-körkép 2018. 2. rész: A műveltségi területek eredményei. $=$ Tudományos és Müszaki Tájékoztatás, 66. évf. 2019. 4. sz. 187-210.p. 
Az egyetemi vagy föiskolai könyvtáros diplomával rendelkező szakemberek az alapvetően fontos digitális kompetenciák birtoklásában erősebbek a pedagógusoknál. Közel 10 százalékkal vagy azt meghaladóan nagyobb arányban vannak a könyvtárosok között haladó szinten állók az információkeresés, az információ értékelése, az online aktivitás, a tartalommegosztás, a digitális kommunikációt szolgáló eszközök kiterjedt használata, a feladathoz illeszkedő technológia megválasztása és az egészségvédelem területén.

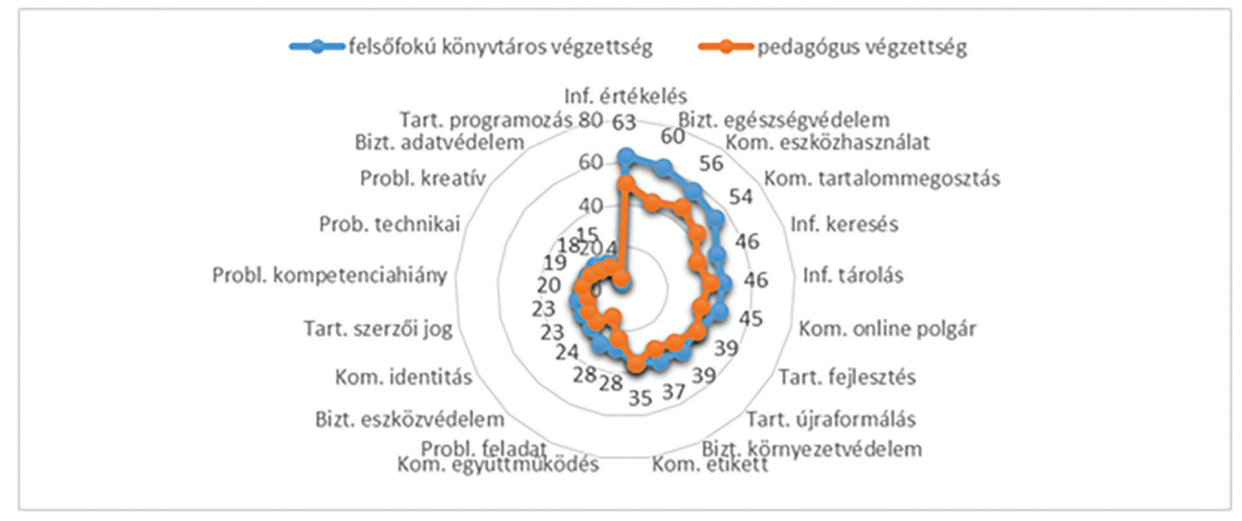

6. ábra. Könyvtáros diplomával rendelkező könyvtárosok és pedagógusok haladó jártassági szintjei

Az eddigiekben ismertetett eredményekből az a következtetés vonható le, hogy a felsőfokú könyvtárosképzés lényegesen erőteljesebb hatást gyakorol a digitális kompetencia fejlesztésére, mint a pedagógusképzés.

Természetesen mind a könyvtárosok, mind pedig a pedagógusok mintáját eltérö életkori csoportokhoz tartozó szakemberek alkották. Mindkét vizsgálat esetében az életkori arányok reprezentálták az adott szakterület meglévő életkori összetételét. Ennek ellenére joggal merülhet fel az a kétely az eredményekkel kapcsolatban, hogy valószínüleg a könyvtáros és a pedagógus minta különböző életkori arányai okozhatták az egyértelmü könyvtáros fölényt. Az esetleges kétségek eloszlatása céljából érdemes kiemelten tanulmányozni a friss diplomás, a húszas éveikben járó könyvtárosok és pedagógusok digitális jártasságát. Ezt segíti a 7. ábra is. A pályakezdők esetében az látható, hogy valamennyi kompetenciaterületen nagyobb a kompetenciakülönbség annál, mint ami a teljes könyvtáros és pedagógus mintában volt tapasztalható. A fiatal könyvtáros szakemberek lényegesen jobban képesek digitális környezetben információt menedzselni (keresni, értékelni, tárolni), tartalmat elóállítani és tájékozottabbak a digitális biztonság témakörében is. A digitális kommunikáció és a problémamegoldás területén is erősebb jártassággal rendelkeznek pedagógus kortársaiknál. A pálya- 
kezdő könyvtárosok kompetencia fölényét nemcsak a haladó jártassági szintek nagyobb aránya jelzi, hanem az is, hogy négy kompetenciaterületen rendelkeznek közülük kevesebben alapszintủ jártassággal, mint a pedagógusok közül. A digitális kommunikáció kompetenciaterületen mindkét csoportban 14,5 százalék az alapszintet birtoklók aránya.

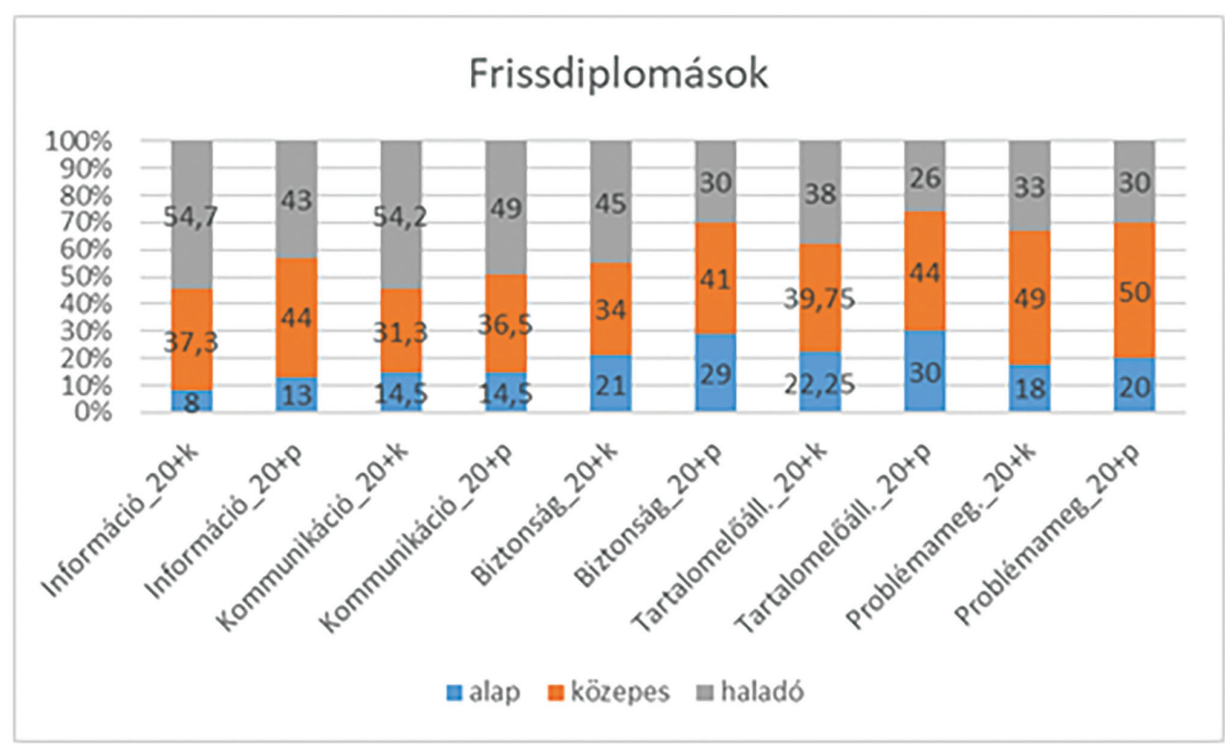

7. ábra. Friss diplomás könyvtárosok és pedagógusok

Könyvtáros hallgatók és gazdaságinformatikus hallgatók digitáliskompetenciaeredményei

Az informatikus könyvtáros alapképzési szakon és a könyvtártudományi mesterképzési szakon tanuló hallgatók száma az utóbbi évek beiskolázási gyakorlatát érintő változtatások miatt országos szinten drasztikusan csökkent. Emiatt tekinthető a 2019-es kompetenciavizsgálatban résztvevő mindössze 27 fös minta reprezentatívnak a könyvtárszakos hallgatók vonatkozásában. Eredményeiket a 8. ábra tartalmazza. 


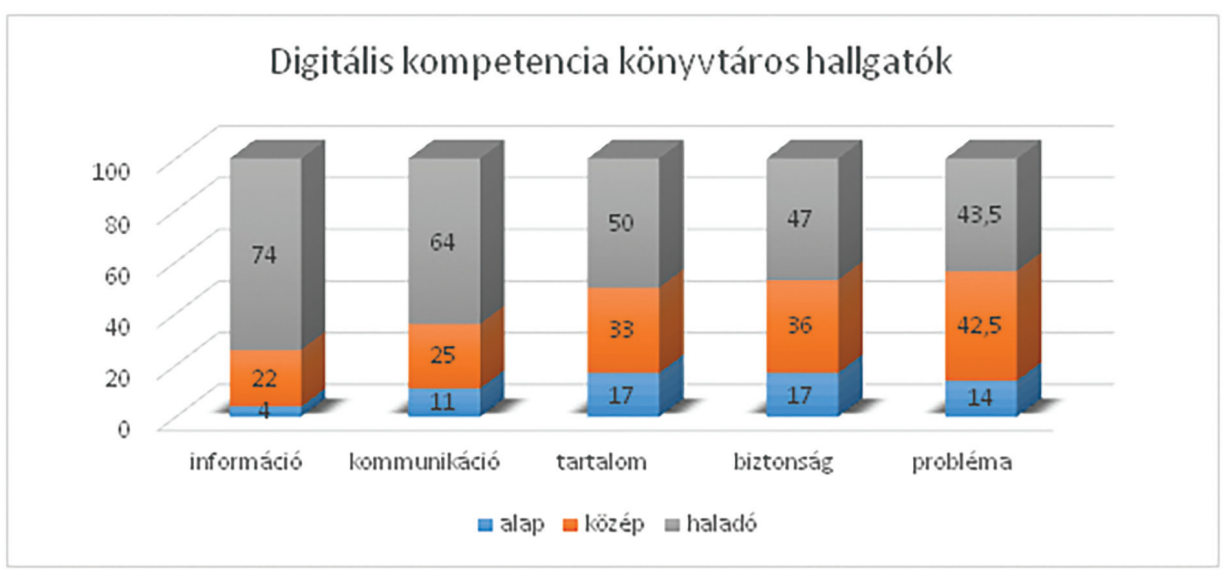

8. ábra. Könyvtáros hallgatók digitális kompetencia állapota

A könyvtárszakos hallgatók esetében a digitális kompetenciaterületeknek ugyanaz az erösorrendje alakult ki, mint az aktív könyvtárosok körében, de az egyes jártassági szintek aránya már jelentős különbségeket mutat a két csoport között. A hallgatókat sokkal nagyobb arányú haladó jártassági és lényegesen kisebb arányú alapjártassági szintek jellemzik, mint a könyvtárosokat. Az információ digitális környezetben történő menedzselése kiemelkedően stabil kompetenciája a hallgatóknak, háromnegyedük véli úgy, hogy haladó szintüek a készségeik. A gyakorló könyvtárosnak kevesebb mint fele gondolta magáról ugyanezt. Nagyon erősnek tartják a hallgatók a digitális kommunikálás világában szükséges kompetenciáikat is, 64 százalékuk áll haladó szinten. Még a körükben leggyengébbnek bizonyuló problémamegoldás területén is 44 százalék a legmagasabb jártassággal rendelkezők aránya. Talán a haladó jártasság kiemelkedően jó mutatóinál is fontosabb az a tény, hogy a könyvtárszakos hallgatók között csak nagyon kis arányban vannak azok, akiknek a digitális jártassága pusztán alapszinttel írható le.

Talán nem túlzás azt állítani, hogy a könyvtáros szakmában munkáltatói oldalról mind a mai napig van egy kis bizonytalanság abban, hogy mi is várható el egy végzett informatikus könyvtárostól, holott a végzettség és a szakképzettség megnevezése csak a szakmával szembeni megváltozott elvárásokat képezte le. Ma már nem képzelhető el felsőfokú szakirányú végzettségü könyvtáros szakember használható informatikai jártasság nélkül. Természetesen a képzés során sem egyszerủ a két terület oktatása, az informatika és a könyvtártudomány szimbiózisát folyamatosan szem elött tartva és legalább törekedve annak elérésére.

A könyvtárosképzéshez nagyon hasonló sok tekintetben a viszonylag új keletủ gazdaságinformatikus-képzés. Ennek során sem sokkal egyszerübb a helyzet, 
mivel ebben az esetben úgy kell informatikai szakembereket képezni, hogy eközben jó gazdasági szakemberekké is váljanak, vagy éppen fordítva. Ez a hallgatók körében is okoz némi bizonytalanságot a saját kompetenciáik reális megitélésében.

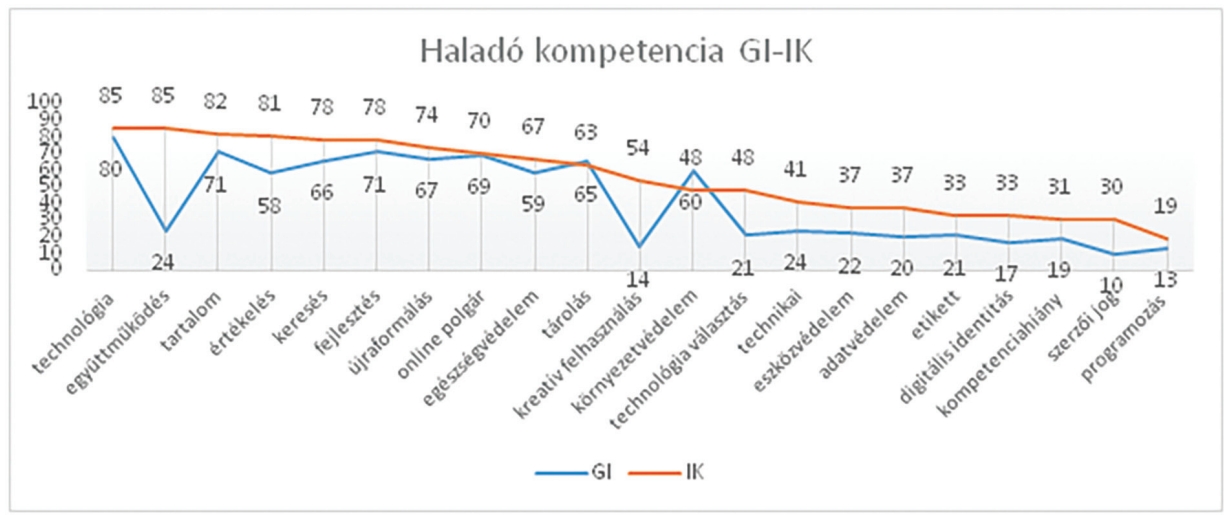

9. ábra. Könyvtárszakos és gazdaságinformatikus hallgatók haladó jártassági szintjei

Valamelyest a véletlennek is köszönhető, hogy éppen a könyvtárosok és a könyvtáros hallgatók körében zajló vizsgálatok során nyílt lehetőség a gazdaságinformatikus hallgatók digitális kompetenciáinak felmérésére is. Ugyanakkor az eredményeik nagyon jó viszonyítási alapot jelentenek ahhoz, hogy reálisabban lássuk a könyvtárszakos hallgatók, és talán a könyvtárosképzés teljesítményét is ezen a területen. A könyvtáros és gazdaságinformatikus hallgatók haladó jártassági szintjeit az egyes kompetenciák szerint a 9. ábra tartalmazza. Egyik szak hallgatóival szemben sem tekinthető túlzó elvárásnak, hogy a DigComp keretrendszerben elérhető három jártasság közül jelentős többségük haladó szintűvel rendelkezzen. Éppen emiatt a két csoport kompetencia állapota csak a haladó szint szerint került összevetésre.

Első pillantásra talán meglepö, hogy a könyvtáros hallgatók két kompetencia kivételével - az adatok, információk tárolása és rendezése, valamint a környezetvédelem -, jobb eredményeket értek el, mint a gazdaságinformatikusok. Ugyanakkor figyelembe véve, hogy a DigComp szerinti digitáliskompetenciaértelmezés tulajdonképpen az információs müveltség fogalmának egyfajta kiterjesztése a digitális korra, már nincs is semmi rendkívüli abban, hogy a leendő könyvtárosok egyre felkészültebbnek bizonyulnak ezen a téren.

Általánosságban elmondható, hogy a két hallgatói csoportban a kompetenciák sorrendje nagyon hasonló. Ami gyengébben megy a könyvtárosoknak, az a gazdaságinformatikusoknak sem az erősségük, és a könyvtárosok erősségei jellemzően a gazdaságinformatikusok körében is az erősebb kompetenciák közé tartoznak. Például mindannyian kiterjedten használják a digitális kommunikációt 
szolgáló eszközöket és azok funkcióit, jók a tartalommegosztásban, a digitális tartalmak elóállításában, és nagyon aktívak online polgárként. Mindkét szak hallgatói gyengébb kompetenciákkal rendelkeznek a technikai problémák megoldása, az adatvédelem, az eszközvédelem, a netikett, a saját kompetenciahiány felismerése és felszámolása, a szerzői jog és a programozás területén. Míg az utóbbi inkább a gazdaságinformatikus képzés, addig a szerzői jogi jártasság alacsony szintje a könyvtárosképzés szempontjából rendkívül sajnálatos.

Négy, a könyvtáros szakma szempontjából is rendkívül fontos kompetenciát a könyvtáros hallgatók jelentősen erősebben birtokolnak, mint a gazdaságinformatikusok. A digitális környezetben történő együttmüködés a könyvtáros hallgatók 85 százalékának megy haladó szinten, tehát ők ismernek és használnak is kollaborációra alkalmas alkalmazásokat. A gazdaságinformatikus hallgatóknak alig negyede tartja magát képesnek haladó szintủ együttmüködésre. A könyvtáros hallgatók 54 százaléka gondolja azt, hogy a technológiákat és a digitális eszközöket használva képes hozzájárulni tudás előállításhoz, és részt tud venni innovatív cselekvésekben. A gazdaságinformatikusok mindössze 14 százaléka állítja az előbbieket magáról. Az adott problémahelyzethez, feladatmegoldáshoz legadekvátabb technológia megválasztásában is sokkal felkészültebbnek érzik magukat a könyvtárosok, 27 százaléknyi a haladó jártasság kiterjedtségében a fölényük. A negyedik kompetencia, amely esetében még kifejezett előnyben vannak a könyvtáros hallgatók, az információ és forrás értékelésének képessége.

\section{Összegzés}

A különböző végzettségü könyvtári szakemberek, a pedagógusok és a két egyetemista csoport digitális kompetencia állapotának összehasonlító vizsgálata alapján biztonsággal kijelenthető, hogy a könyvtáros diplomával rendelkezőknek jelentősen erösebbek a digitális kompetenciáik, mint a többieknek. A könyvtáros hallgatók eredményei pedig azt jelzik, hogy a könyvtárosképzés képes folyamatosan lépést tartani a digitális kompetenciák fejlesztése terén a kor kihívásaival, megújítva a képzés tartalmi elemeit.

Nem tünik túlzónak az az állítás, hogy a felsőfokú könyvtárosképzést folytató intézmények valószínủleg jó úton járnak hallgatóik digitális készségeinek fejlesztése terén, ha összehasonlítjuk az aktív könyvtáros diplomával rendelkező könyvtárosok, a néhány éve végzett könyvtáros friss diplomások és a jelenlegi hallgatók kompetencia viszonyait. A 10. ábra az említett három csoport haladó jártassági szintjeit tartalmazza. 


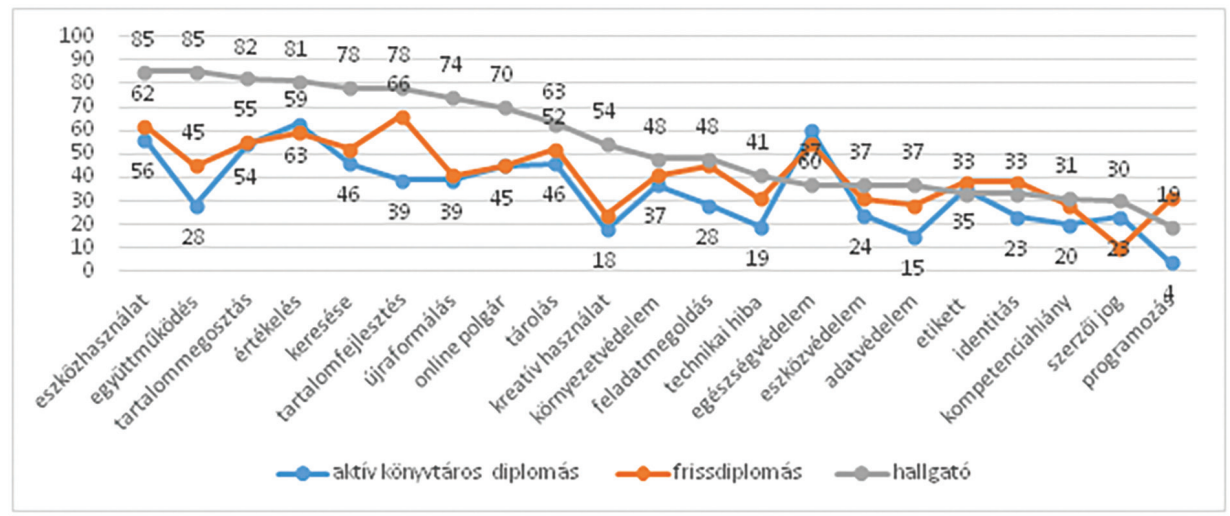

10. ábra. Könyvtárosok, friss diplomások, hallgatók haladó jártassági szintjei

Jól látható az a tendencia, miszerint minél frissebben szerezték a könyvtárosok a diplomájukat, annál erősebb digitális kompetenciákkal rendelkeznek. Csak két kompetencia van, amelyben az aktív, de már nem friss diplomások bizonyultak erősebbnek friss diplomás kollégáiknál vagy a hallgatóknál: az információk és a források értékelésének képessége, valamint a digitális technológia egészségre gyakorolt hatásainak ismerete. Természetesen világosan kirajzolódnak a képzés számára a még javítandó területek is. Mindenképpen fejleszteni kell a hallgatók szerzői jogi ismereteit, programozási készségeit, a digitális biztonság és az online etikett területéhez kapcsolódó kompetenciákat.

\section{Rezümé}

A közelmúltban az EFOP-3.3.3-VEKOP-16-2016-00001 Múzeumi és könyvtári fejlesztések mindenkinek pályázati konstrukció $A z$ én könyvtáram címü kiemelt projektjének keretében két országos reprezentatív felmérés valósult meg digitális kompetencia témában. Az egyikben közel kétezer könyvtáros, a másikban pedig több mint nyolcszáz pedagógus vett részt. További vizsgálatok is zajlottak gazdaságinformatikus és informatikus könyvtáros egyetemista hallgatók körében, arra keresve a választ, hogy a képzés milyen hatást gyakorol a digitális kompetencia állapotukra. A tanulmány bemutatja a kutatások legfontosabb eredményeit, részletesen ismertetve, hogy melyek azok a digitáliskompetencia-területek és kompetenciák, amelyek esetében egyértelmüen kimutatható a képzés és a végzettség kompetenciaszintet befolyásoló hatása. A kutatás eredményei tényszerủen igazolták, hogy a felsőfokú könyvtárosképzés kifejezetten nagy mértékben erösíti a hallgatók digitális kompetenciáit. 


\section{A study to examine the impact of different academic qualifications on the digital competence levels of employees}

Recently two national representative surveys were organized by the Museum and Library Development for Everyone My Library EFOP-3.3.3.-VEKOP/16-2016-00001 project in the digital competence topic. One of them involved nearly two thousand librarians, while more than eight hundred teachers participated in the other. Further investigations were also conducted among students of library and information science and business informatics. The main target of the student surveys was to explore the effect of education on their digital competence condition. The study presents the most important findings of the surveys, and details those digital competence areas and competences which are in unambiguous connection with the qualifications. The results of the research factually demonstrated that the librarian training at the academic level markedly improves the students' digital competences.

ESZENYINÉ BORBÉLY MÁRIA adjunktus

Debreceni Egyetem Informatikai Kar ORCID: 0000-0002-1161-1419 